\title{
REVITALISASI KADER ASI DALAM PROGRAM PRANATAL UNTUK KEBERHASILAN MENYUSUI
}

\author{
Rini Kristiyantia ; Milatun Khanifah ${ }^{\mathrm{b}}$; Nur Chabibah ${ }^{c^{*}}$ \\ a, b, c Program Studi Kebidanan; Universitas Muhammadiyah Pekajangan Pekalongan \\ Jl. Raya AmbokembangNo.8; Kedungwuni, Pekalongan, Jawa Tengah, Indonesia
}

\begin{abstract}
Abstrak
Pemberian ASI Eksklusif di Indonesia belum optimal, masalah utama adalah masih rendah kesadaran masyarakat. Dukungan kader yang terlatih membantu dalam suksesnya kegiatan ASI ekslusif pada ibu. Kegiatan ini bertujuan untuk pemantapan kembali peran kader ASI dalam pendampingan kelas ibu hamil sehingga meningkatkan keberhasilan ASI Eksklusif. Program pengabdian kepada masyarakat ini menggunakan metode dan media berupa penyuluhan terstuktur, focus group discussion dan praktik teknik edukasi ASI Eksklusif, Teknik Menyusui, Teknik Memerah ASI dan ASI eksklusif pada ibu bekerja. Pelaksanaan kegiatan dilaksanakan pada 24 Kader ASI di 8 Desa wilayah kerja Puskesmas Kedungwuni II selama enam bulan. Hasil kegiatan adalah peningkatan pemahaman kader mengenai manajemen laktasi dengan nilai rata-rata pre test 90,5 dan post test 93,1. Pada saat pendampingan kader ASI dilakukan observasi kader saat pemberian edukasi pada ibu hamil mengenai persiapan laktasi dan didapatkan nilai rata-rata praktik dan pendampingan adalah 87,7 dan 85,5. Simpulan program revitalisasi kader ASI ditindaklanjuti dengan komitmen Puskesmas Kedungwuni II untuk melanjutkan kegiatan yang telah berjalan dengan pendampingan menyusui sejak ibu hamil sampai menyusui.
\end{abstract}

Kata kunci: Menyusui, Revitalisasi, Kader

\begin{abstract}
[REVITALIZATION OF THE BREAST MILK CADER IN PRANATAL PROGRAMS FOR SUCCESSFUL BREASTFEEDING] Exclusive breastfeeding in Indonesia is not optimal, the main problem is the low level of public awareness. The support of trained cadres helps in the success of exclusive breastfeeding activities for mothers. This activity aims to re-establish the role of breastfeeding cadres in mentoring classes for pregnant women so as to increase the success of exclusive breastfeeding. This community service program uses methods and media in the form of structured counseling, focus group discussions and practices of exclusive breastfeeding education techniques, breastfeeding techniques, expressing techniques and exclusive breastfeeding for working mothers. The activity was carried out on 24 ASI cadres in 8 villages in the working area of the Kedungwuni II Community Health Center for six months. The result of the activity was an increase in the cadres' understanding of lactation management with an average pre-test score of 90.5 and posttest 93.1. At the time of mentoring cadres of breastfeeding, observations of cadres were carried out when providing education to pregnant women about lactation preparation and the average values of practice and mentoring were 87.7 and 85.5. Conclusion the breastfeeding cadre revitalization program is followed up with the commitment of the Kedungwuni II Community Health Center to continue the activities that have been running with breastfeeding assistance from pregnant women to breastfeeding.
\end{abstract}

Key words: breastfeeding, revitalization, kader

\section{Pendahuluan}

Air Susu Ibu (ASI) adalah nutrisi terpenting sebagai sumber energi untuk bayi dari usia 0 sampai dengan 23 bulan. ASI mencukupi seluruh kebutuhan nutrisi bayi,

*) Correspondence Author (Nur Chabibah)

E-mail: nchabibah@ymail.com bahkan kandungan nutrisinya data mencapai satu setengah dari energi yang dibutuhkan bayi. Demikian juga pada kondisi sakit banyak zat aktif yang memperkuat imunitas bayi sehingga dapat mengurangi resiko kematian bayi dan anak (Proverawati A\& Asfufah S, 2010), akan tetapi pemberian ASI belum cukup optimal dilakukan oleh para ibu. Prosentase ibu 
menyusui secara ekslusif sebesar 35,7\% meningkat dibandingkan tahun 2013 sebesar $30,2 \%$, akan tetapi peningkatan tersebut belum sesuai dengan target nasional dengan target capaian sebesar $80 \%$ (Kementrian republik Indonesia, 2018). Kesadaran masyarakat yang kurang dalam mendukung program pemberian ASI merupakan penyebab utama masih jauhnya ketercapaian program nasional tersebut. Masyarakat seyogyanya dapat mempertimbangkan perbedaan kandungan susu formula dan ASI, terutama dalam mendukung imunitas bayi, ASI memeliki kandungan Karotenoid dan Selenium yang berfungsi dalam menunjang pertahanan tubuh bayi darai serangan penyakit. Selain itu kandungan mineral dan enzim yang berfungsi sebagai antibodi yang tidak terkalahkan oleh susu lainnya (Danso, 2014).

Tantangan terbesar tenaga kesehatan dalam meningkatkan cakupan ASI Eksklusif adalah faktor sosial budaya, pengetahuan yang kurang akan pentingnya ASI baik pada ibu hamil dan keluarga. Ditambah dengan belum optimalnya dukungan instansi maupun jajaran kesehatan lainnya dalam upaya mendukung ketercapaian target ASI Eksklusif. Kebijakan program ASI Eklusif ini belum dibarengi oleh pengendalian promosi susu formula, dukungan perusahaan dalam pemberian fasilitas laktasi di tempat bekerja maupun kebijakan cuti untuk ibu yang menyusui (Kementrian Republik Indonesia, 2011).

Peran serta suami dan anggota keluarga terdekat, termasuk petugas kesehatan dan masyarakat di lingkungan ibu menyusui menjadi kunci dalam suksesnya pemberian ASI. Peran ini dapat dimulai pada saat kehamilan dalam perencanaan laktasi sampai dengan setelah melahirkan untuk memulai pemberian ASI dini pada bayinya hingga berusia 23 bulan. Peran serta masyarakat dapat diwujudkan dengan melatih sebagian dari masyarakat sebagai kader ASI yang dapat membantu dalam pelayanan terpadu terutama pada pemberian edukasi persiapan laktasi sampai dengan masa laktasi setelah melahirkan dan memantau kendala-kendala yang ditemui ibu menyusui saat praktik pemberian ASI. Dengan demikian peran masyarakat yang terlatih sangat besar peranannya dalam membantu ibu dan menfasilitasi komunikasi tenaga kesehatan dengan ibu menyusui sehingga di harapkan peningkatan target cakupan ASI Eksklusif akan dapat di capai apabila ada upaya bersama dari masyarakat untuk mewujudkan generasi yang sehat dan kuat. Puskesmas Kedungwuni II bersama dengan Universitas Pekajangan Pekalongan pada Tahun 2017 telah melaksanakan kegiatan pelatihan Kader ASI dengan menghasilkan 24 Kader ASI di 8 Desa binaan Puskesmas Kedungwuni II, akan tetapi pelatihan ini belum cukup untuk meningkatkan cakupan ASI eksklusif. Oleh karena itu tim pengabdian masyarakat melakukan analisa kegiatan kader ASI dalam peningkatan cakupan ASI pasca pelatihan kader ASI. Ditemukan beberapa factor antara lain pembekalan praktik penyuluhanyg blm maksimal karena kurangnya media yg digunakan hanya berupa lembar balik, pengalaman praktik penyuluhan yang terbatas dan rasa percaya diri kader yang kurang, sehingga tim bersama denan pihak puskesmas kedungwuni II padatahun 2019 melaksanakan revitalisasi kader ASI pada 24 kader ASI yang sudah pernah dilatih sebelumnya untuk refresh pengetahuan, meningkatkan ketrampilan penyuluhan dan konseling dan memberikan bekal media penyuluhan yang lebih beragam.

\section{Metode}

Program Pengabdian Kepada Masyarakat (PkM) ini menggunakan metode penyampean dengan beberapa teknik diantaranya penyuluhan terstuktur, focus group discussion dan praktik teknik edukasi ASI Eksklusif, Teknik Menyusui, Teknik Memerah ASI dan ASI eksklusif pada ibu bekerja. PkM ini dilakukan secara terjadwal dan dilakukan langkah demi langkah. Langkah pertama yang dilakukan oleh tim adalah identifikasi masalah. Identifikasi masalah dilakukan dengan cara menggali pengetahuan dan ketrampilankader tentang peran kader dalam mendukung gerakan ASI Eksklusif. Identifikasi masalah dilaksanakan dengan pendekatan pada bidan koordinator, sejumlah bidan desa dan beberapa kader untuk mengetahui permasalahan dan kebutuhan kesehatan yang ada pada kelompok sasaran serta untuk mengetahui kemauan dan kemampuan kader guna menentukan pendekatan, waktu dan pelaksanaan kegiatan dilakukan.

Permasalah-permasalah tersebut dianalisa sebagai dasar penyusunan rencana kegiatan sebagai langkah pemecahan masalah kesehatan pada sasaran. Masalah yang didapatkan dari hasil identifikasi antara lain pengetahuan tentang teknik menyusui dan aplikatif ASI 
pada ibu bekerja yang masih kurang, serta masih berkembangnya mitos seputar ASI yang tidak tepat dan menjadi penyebab kegagalan dalam ASI eksklusif.

Metode Penyuluhan terstuktur dilakukan pada saat penyampaian materi tentang ASI eksklusif, Teknik Menyusui dan ASI pada ibu Bekerja. Metode diskusi tanya jawab digunakan terintegrasi pada saat ceramah dan juga sebagai salah satu metode saat dibutuhkan konsultasi. Demonstrasi digunakan sebagai metode pendidikan kesehatan pada setiap materi untuk memperlihatkan pada cara melakukan edukasi dengan benar dan tepat. Focus group Disscusion digunakan pada praktik metode-metode yang sudah diajarkan melalui metode demonstrasi sehingga kader dapat mempraktekan dan diberi bimbingan secara langsung oleh pendamping Kader ASI. Peralatan yang digunakan dalam PkM ini antara lain lembar balik, phantom payudara, phantom peraga ukuran lambung bayi, gelas cangkir dan gelas minum bayi, handuk dan tempat cuci tangan, alat tulis, laptop, LCD dan infokus.

Prosedur dalam kegiatan pengabdian masyarakat ini yaitu diawali dengan permohonan dari pihak mitra dalam penyediaan nara sumber pada kegiatan bidang kesehatan di Puskesmas Kedungwuni II dan selanjutnya Lembaga Penelitian, Pengabdian dan Inovasi Universitas Muhgammadiyah Pekajangan Pekalongan memberikan rekomendasai kepada dosen Prodi Diploma III Kebidanan untuk menindaklanjutinya. Tim dosen prodi Diploma III Kebidanan melakukan pendekatan kepada mitra untuk identifikasi masalah dan penyusunan rencana kegiatan.

Kegiatan pengabdian kepada masyarakat dalam meningkatkan pengetahuan, motivasi dan ketrampilan Kader ASI dalam memberikan penyuluhan dan pendampingan ASI Eksklusif kepada sasaran yang ada di Wilayah Kerja Puskesmas Kedungwuni II Kabupaten Pekalongan dilakukan selama 6 bulan di aula Puskesmas, dilanjutkan di masing-masing desa sebanyak delapan desa dan di sesi akhir evaluasi dan penyususnan rencana tindak lanjut di Aula Puskesmas Kedungwuni II.

\section{Hasil dan Pembahasan}

Program kemitraan masyarakat ini dilaksanakan selama enam bulan, dengan tahapan kegiatan sebagai berikut:

Melakukan pendekatan dengan cara mengirim surat balasan kesanggupan permohonan sebagai nara sumber pada kegiatan Revitalisasi Kader ASI pada kelas Prenatal untuk Mendukung sukses menyusui. Dilanjutkan dengan koordinasi dengan Bidan Koordinator dan masing - masing bidan desa di Puskesmas Kedungwuni II untuk identifikasi masalah, penyusunan rencana kegiatan, persiapan alat dan tempat serta teknis kegiatana. Identifikasi masalah dilakukan dengan cara melakukan interview pada tenaga kesehatan dan kader di wilayah tersesbut.

Pelaksanaan Kegiatan dilaksanakan antara lain sebagai berikut:

\section{a. Refreshing Kader ASI}

Kegiatan Refreshing kader selama dua hari dilaksanakan di Puskesmas Kedungwuni II dengan mengundang kader ASI masingmasing desa yang tahun sebelumnya telah mengikuti kaderisasi kader ASI namun belum maksimal dalam pelaksanaan kampanye ASI Eksklusif di Desanya. Peserta refresing kader sejumlah 22 orang yang merupakan perwakilan kader dari delapan desa di wilayah kerja kedungwuni II.

Fungsi kader dalam kegiatan ini adalah menjadi fasilitator antara petugas keshatan dan masyarakat, terutama sasaran ibu hamil dam ibu menyusui. Sehingga kader diharapkan dapat memberikan informasi-informasi dari masyarakat pada petugas kesehatan yang belum dapat kontak langsung dengan masyarakat. Kader diharapkan bisa menjadi sumber daya masyarakat terutama dalam mengadvokasi masyarakat serta membangun kemampuan lokal (Iswarawanti, 2010).

Pada pekasanaan kegiatan ini di berikan materi tentang ASI Eksklusif, Teknik menyusui yang benar, dan pemerahan ASI, dan ASI pada Ibu bekerja baik dengan teknik ceramah tanya jawab dan demonstrasi. Kegiatan refresing ini untuk memperdalam pengetahuan kader tentang manfaat ASI. Manfaat ASI tidak sebatas pada bayi tapi juga untuk masa balita bahkan sampai bayi dewasa dewasa kelak, namun ASI dapat mengoptimalkan perubahan anak untuk meraih potensi yang ada dengan sempurna. ASI juga bermanfaat bagi ibu bahkan bagi Negara (Oktalina, O., Muniroh, L., \& Adiningsih, 2016).

Pada pelaksanaan kegiatan ini seluruh kader ASI dari delapan Desa di wilayah kerja Puskesmas Kedungwuni II mengikuti kegiatan ini penuh antusias. Media peraga yang digunakan cukup interaktif dan membuat peserta antusias dalam mengikuti kegiatan. 
Penelitian yang dilakukan oleh Suyanto (2017) menunjukkan bahwa adanya pelatihan kader dapat meningkaykan tingkat pengetahuan secara signifikan pada kader $\mathrm{p}$ value $=0.001$. Hal ini menunjukkan adanya perubahan pengetahuan kader setelah diberikan rangsangan berupa pelatihan. Selain itu, kader juga memerlukan penyegaran informasi dan pengetahuan terutama tentang ASI eksklusif agar dapat memberikan pendampingan pada ibu menyusui (Suyanto, A. A., \& Nurfa'izah, 2017).

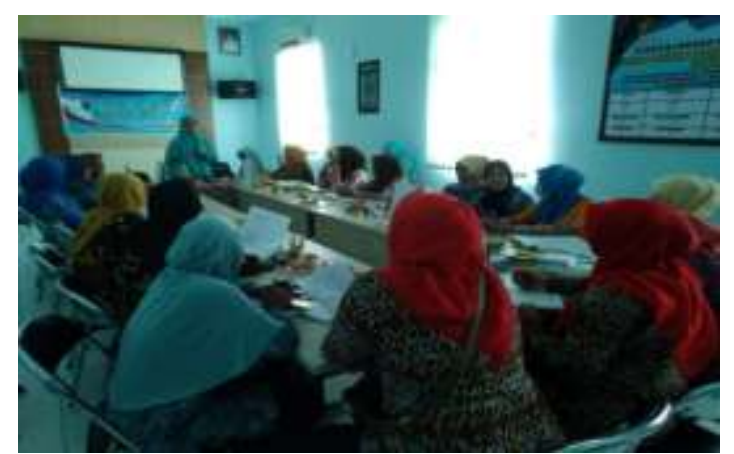

Gambar 1. Kegiatan Review Materi Kader ASI di Puskesmas

b. Pendampingan kader ASI di Delapan Desa Kegiatan pengabdian dilanjutkan dengan pendampingan kader ASI dalam pemberian kampanye ASI Eksklusif dengan kelompok sasaran Ibu Hamil di masingmasing Desa. Kegiatan ini merupakan bentuk evaluasi Refreshing Kader ASi yang telah diselenggarakan sebelumnya sehingga dapat meningkatkan ketrampilan maupun kepercayaan diri Kader ASI. Fungsi pendampingan kader ASI adalah sebagian dari aspek pembinaan kader sehingga dapat memotivasi kader salam upaya promosi kesehatan terutama tentang ASI Eksklusif. Sebagaimana diutarakan oleh Hanan (2012) kebutuhan kader kesehatan terkait upaya promosi kesehatan khususnya tentang ASI eksklusif adalah pembinaan dar pihak puskesmas terutama tentang cara penyampaian informasi kepada masyarakat sehingga informasi informasi yang diberikan kepada masyarakat dapat di terima oleh masyarakat (Hanan U., 2012). Nursalam (2009, dalam Hanan; 2012) menambahkan bahwa fungsi pembinaan adalah untuk membuat kader melaksanakan tugas sesuai dengan apa yang diinginkan untuk mencapai tujuan organisasi, meningkatkan semangat tim dalam koorporasi (Hanan U., 2012).

Kegiatan pendampingan kader ASI ini dilaksanakan di kelas ibu desa Ambokembang, Pekajangan, Tangkil Kulon, Tangkil Tengah, Kedungpatangewu, Karangdowo, Bugangan dan Rengas berlangsung lancar. Kader ASI dapat melaksanakan perannya dalam pemberian Edukasi persiapan menyusui pada ibu hamil. Masyarakat sasaran dalam hal ini ibu hamil pada saat pelaksanaan kegiatan sangat antusias mengikuti pendampingan menyusui, dan aktif bertanya seputar persiapan menyusui, ASI eksklusif dan masalah dalam menyusui. Kader ASI yang berperan dalam pendampingan sangat aktif dalam memberikan pendidikan kesehatan, walaupun terdapat kekurangan yaitu tingkat percaya diri kader yang belum maksimal. Dengan adanya dukungan dari bidan desa kader menjadi bertambah

Dalam proses pendampingan ini kader dibekali juga dengan media berupa lembar balik dan alat peraga dalam memperagakan teknik menyusui, pemerahan ASI hingga pemberian ASI. Media ini duganakan untuk mempermudah penangkapan informasi pada sasaran ibu hamil sehingga pesan yang tersampaikan jelas dan dapadi implementasikan dengan tepat.

Fungsi media dalam pendidikan adalah sebagai alat peraga untuk menyampaikan informasi atau pesan pesan tentang kesehatan. Sebagaimana dikemukakan oleh Rahmawati (2015) mengemukanan bahwa terdapat pengaruh penggunaan media berupa buku saku pada kelompok pendukung ibu menyusui tentang permasalahan dalam pemberian ASI pada variabel pengetahuan ( $p$-value $=0,0001$ ) artinya penggunaan media berupa buku saku mempengaruhi pengetahuan kelompok pendukung ASI dalam permasalahan pemberian ASI (Rahmawati, N. I., Nugraheni, S. A., \& Mawarni, 2015).

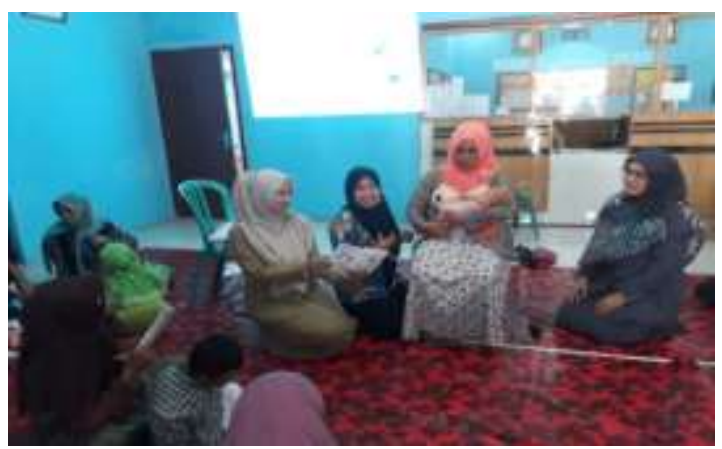

Gambar 2. Pelaksanaan Praktik Pendampingan kader ASI di Kelas Ibu Hamil 


\section{c. Kegiatan Evaluasi dan Penyusunan Rencana Tindak Lanjut}

Evaluasi Kader ASI dalam Refreshing kader ASI dan pendampingan kader ASI bertujuan untuk mengapresiasi hasil kampanye ASI Eksklusif yang telah dilakukan oleh kader ASI. Evaluasi kegiatan revitalisasi kader ini dilakukan dengan tes tulis, tes praktik dan tes praktik pendampingan. Tes tulis di laksanakan dengan membagikan kuisiner pada pre tests yang dilaksanakan sebelum pemberian refresh materi dan post tes yang dilakukan di akhir sesi ceramah dan tanya jawab materi refresh terkait ASI Eksklusif. Kuisioner yang digunakan terdiri dari 20 item pertanyaan. Penilaian praktik dilaksanakan dengan ceklist praktik penyuluhan dan tindakan yang terdiri dari praktik penyusluhan ASI Eksklusif, Praktik temnik Menyusui dan Praktik Pemerahan dan Penyimpanan ASI.

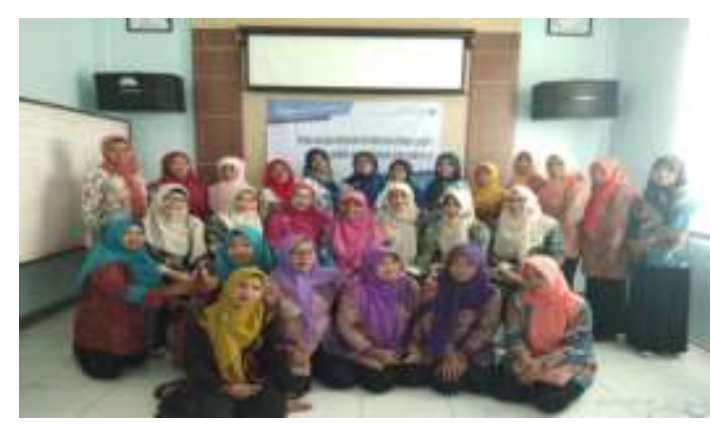

Gambar 3. Kegiatan Evalusi dan Penyusunan Tindak Lanjut Kader ASI

Penilaian praktikm oleh kader ini dilakukan oleh bidan desa yang telah mengikuti persamaan persepsi dengan tim yang melaksanakan refresing materi praktik. Penilaian berikutnya adalah penilaian pendampingan pada saat kader ASI mengisi kelas ibu hamil. Penilaian pendampingan ini diksanakan oleh tim PkM. Hasil refreshing kader ASI didapatkan nilai evaluasi tertulis didapatkan rata-rata pre test 90,5 dan nilai ratarata post test 93,1. hasil tersebut menunjukkan adanya peningkatan dalam pemahaman mengenai manajemen laktasi.

Kecukupan pengetahuan dan ketrampilan kader ASI diharapkan dapat menjadi bekal para kader dalam mendampingi ibu hamil yang merencanakan menyusui untuk mantapmemberikan ASI dan membekali ibu dengan pengetahuan yang cukup akan manfaat dan praktik pemberian ASI pada 6 bulan usia bayi, sehingga ibu dapat menyelesaikan tugas pemberian ASi tidak sampai 6 bulan saja tetapi sampai dengan 2 tahun. Menurut Abdullah et.al (2013) ada perbedaan lama pemberian ASI secara penuh berdasarkan variabel keadaan fisik ibu, pengetahuan ibu, pendidikan, dan pekerjaan.Hasil analisis menunjukkan variabel yang berbeda secara nyata dalam hubungan dengan durasi pemberian ASI secara penuh adalah keadaan fisik ibu dan pengetahuan ibu (Abdullah, M. T., Maidin, A., \& Amalia, 2013).

Pada saat pendampingan kader ASI dilakukan observasi kader saat memberikan penyuluhan kepada ibu hamil mengenai persiapan menyusui meliputi ASI Eksklusif, teknik menyusui, dan pemerahan ASI. Hasil rata-rata penilaian praktik adalah 87,7 dan nilai pendampingan adalah 85,5. Hal ini menunjukkan bahwa praktik kader dalam memberikan pendidikan kesehatan pada ibu hamil tentang manajemen laktasi baik. Hasil ini dapat meningkatkan kepercayaan diri dan ketrampilan kader ASI dalam melakukan pendampingan pada ibu hamil untuk persiapan menyusui, meningkatkan motivasi dalam mendukung keberhasilan menyusui melalui pendampingan ibu hamil, dengan harapan cakupan ASI eksklusif dapat meningkat.

Evaluasi program kegiatan pengabdian kepada masyarakat ini melibatkan tim pengabdian kepada masyarakat, bidan koordinator, bidan desa, serta kader ASI di wilayah kerja Puskesmas dimana pada kegiatan evaluasi tersebut dipaparkan hasil seluruh kegiatan selama 6 bulan dan menyusun rencana tindak lanjut untuk selanjutnya, dimana diharapkan kader ASI senantiasa aktif dalam melaksanakan program mensukseskan ASI eksklusif dengan bekerja sama dengan bidan desa sebagai penanggungjawab program. Evalusi program yang belum bisa dinilai dalam waktu 6 bulan pelaksanaan PkM adalah peningkatan cakupan ASI Eksklusif di masing masing desa. Data cakupan ASI Eksklusif Puskesmas Kedungwuni II tahun 2019 ke tahun 2020 menunjukkan adanya peningkatan cakupan ASI eksklusif 25.4\% mejadi 57.75\%. Widiastuti (2017) dalam pengabdiannya memaparkan bahwa pelatihan persiapan dan pendampingan ASI Eksklusif tidak hanya meningkatkan pengetahuan ibu hamil saja, tetapi hasil elatihan pada ibu yang telah bersalin didapati telah menerapkan ASI eksklusif, termasuk pada ibu primigravida (Widiastuti, A., Yuliani, D. R., Zuhriyatun, F., \& Ramlan, 2017). 


\section{Kesimpulan}

Kegiatan menunjukan adanya peningkatan pengetahuan kader dan ketrampilan pemberian penyuluhan baik pada saat praktik demonstrasi saat pelatihn maupun pada saat praktik pendampingan di kelas ibu hami masing masing desa. Selain itu, terdapat peningkatan cakupan ASi Eksklusif di wilayah kerja Puskesmas Kedungwuni II. Rencana berikutnya adalah pengagendaan rutin penyuluhan dan pendampingan kader ASI dalam setiap kegiatan Kelas Ibu dan Posyandu di desa masing-masing dan Home visit Kader ASI. Untuk itu, diperlukan peran serta seluruh elemen masyarakat dalam mensukseskan program yang dilaksanakan. Pengabdian berikutnya hendakanya dilaksanakan dengan pertimbangan waktu disesuaikan dengan masing-masing elemen sehingga proses pendampingan Kader ASI dapat berjalan secara maksimal.

\section{Ucapan Terima Kasih}

Terima kasih disampaikan kepada Universitas Muhammadiyah Pekajangan yang telah mendanai proses kegiatan pengabdian ini, Puskesmas Kedungwuni II khususnya bidan koordinator dan bidan desa yang telah membantu jalannya kegiatan pengabdian masyarakat ini, serta seluruh kader ASI yang telah berpartisipasi aktif dalam melaksanakan pendampingan ASI pada ibu sejak kehamilan sampai masa nifas dan menyusui.

\section{Daftar Pustaka}

Abdullah, M. T., Maidin, A., \& Amalia, A. D. L. (2013) 'Kondisi fisik, pengetahuan, pendidikan, pekerjaan ibu, dan lama pemberian ASI secara Penuh.', National Public Health Journal, 8(5), pp. 210-214.

Danso, J. (2014) 'Examining the Practice of Exclusive Breastfeeding among Professional Working Mothers in Kumasi Metropolis of Ghana.', Internasional Journal of Nursing, 1(1), pp. 11-24.
Hanan U. (2012) 'Pengalaman Kader Kesehatan dalam Promosi Kesehatan Tentang ASI Eksklusif di Posyandu Flamboyan II Kelurahan Rempoa Kotamadya Tangerang Selatan.'

Iswarawanti, D. N. (2010) 'Kader Posyandu: Peranan dan tantangan pemberdayaannya dalam usaha peningkatan gizi anak di Indonesia', Jurnal Manajemen Pelayanan Kesehatan, 13(04), pp. 11-14.

Kementrian republik Indonesia (2018) Riset kesehatan Dasar (RISKESDAS) 2018. Jakarta.

Kementrian repubplik, I. (2011) 'Banyak Sekali Manfaat ASI Bagi Bayi dan Ibu', Kementrian repubplik, Indonesia, pp. 11-12.

Oktalina, O., Muniroh, L., \& Adiningsih, S. (2016) ‘Hubungan Dukungan Suami dan Dukungan Keluarga dengan Pemberian ASI Eksklusif Pada Ibu Anggota Kelompok Pendukung ASI (KP-ASI).', Media Gizi Indonesia, 10(1), pp. 64-70.

Proverawati A\& Asfufah S (2010) Buku Ajar Gizi untuk Kebidanan. 1st edn. Yogyakarta: Nuha Medika.

Rahmawati, N. I., Nugraheni, S. A., \& Mawarni, A. (2015) 'Pengaruh Penggunaan Buku Saku oleh Motivator Terhadap Pengetahuan dan Ketrampilan Motivator dalam Mengatasi Permasalahan Pemberian ASI (di Kecamatan Sewon Kabupaten Bantul)', Jurnal Ners dan Kebidanan Indonesia, 3(2), pp. 64-70.

Suyanto, A. A., \& Nurfa'izah, D. A. (2017) 'Identifikasi Pengetahuan Kader Tentang Persiapan Menjadi Kader Pendamping ASI di Kelurahan Wahno Jayapura.', SAINS: Jurnal MIPA dan Pengajarannya, 17(1).

Widiastuti, A., Yuliani, D. R., Zuhriyatun, F., \& Ramlan, D. (2017) 'Pelatihan persiapan dan pendampingan asi eksklusif', LINK, 13(1), pp. 8-12. 